\title{
Factors Affecting Performance Manager and Its Impact on Competitive Advantage: Studies Small Medium Enterprises (SMEs) in The Shoes Industry Mojokerto East Java Province
}

\author{
Choirul Bashor \\ Professor, School of Economics, \\ Al-Anwar Mojokerto, Indonesia \\ Chamdan Purnama \\ President School of Economics, \\ Al-Anwar Mojokerto, Indonesia,
}

Doi: 10.1515/mjss-2017-0014

\begin{abstract}
This study aims to describe and analyze the factors which affect the performance of managers consisting of entrepreneurial orientation and creativity factors and their impact on competitive advantage. Apart from that in this study also seeks to want to know how big the impact is directly entrepreneurial orientation and creativity to competitive advantage and influence indirectly through manager performance. The research was conducted on a sample of 170 manager's small medium enterprises (SMEs) in the shoe industry Mojokerto East Java Province, sampling using random sampling techniques. Through the analysis of the results of structural equation modeling (SEM) found that the first-factor entrepreneurial orientation and creativity positive effect on manager performance. Second, the factors of entrepreneurial orientation and creativity direct positive effect on the competitive advantage. Third, through manager performance, factors of entrepreneurial orientation and creativity indirectly positively effects on the competitive advantage. Fourth, manager performance positively affects competitive advantage.
\end{abstract}

Keywords: entrepreneurial orientation, creativity, manager performance, competitive advantage, small medium enterprises

\section{Introduction}

Along with population growth and economic development of communities in the Mojokerto East Java Province, the existence of entrepreneur's small medium enterprises (SMEs) is vital to the economic stability of a country (Lennox, 2013: 84). The industry has a role in facilitating the development of the global economy. This is because the sector is seen as an important contributor in the transition to a market economy, through the process of creativity, fostering technological advances, organizational innovation and change, job creation, income generation, economic competitiveness, and other aspects of social development in general, and expansion industrial, in particular (Zamberi, 2012: 217). Most of the population in the region in the area of Mojokerto East Java Province is a businessman small medium enterprises (SMEs) shoe industry.

As usual footwear models made the variable in both shape and size. Businessman creativity is needed in providing satisfaction to the customers so that the company can compete. The design is the purposive application of creativity to all the activities Necessary to bring ideas into use either as the product (service) or process innovations (Besant et al., 2005). For entrepreneurs to small medium enterprises (SMEs) can remain competitive should continue to increase competitiveness 
by launching new products or services as customer demands and competition from other companies (Man et al., 2002).

Creativity in the company is very necessary for this era of globalization (Coelho at al., 2011). Creativity alone will not provide optimum results if it is not supported by the human resources manager who has a high performance. Manager performance is the work of a manager of the company from the managerial aspects in the use of corporate assets to reach the wealth creating ability and the institution through need some other people who were in the area authority. (Mulyadi and Setyawan, 2000: 164) is the manager's responsibility to coordinate, foster, directing and controlling the activities of the employees towards the achievement of organizational goals. At this time the company should focus on fostering entrepreneurship and creativity (Kwasniewska and Necka, 2004). The focus on entrepreneurship and creativity can help companies to open new markets. (Kim and Mauborgne, 2004: 76).

Associated with entrepreneurship orientation Miller (1983) provides an operational concept, an entrepreneurship orientation as an orientation for trying to be the first in product innovation, market, risk-taking, and undertake proactive measures to beat the competition. While Lumkin and Dess (1996) states that entrepreneurial orientation is willing to take, unlike the conservative nature of the company to survive and avoid risks in an effort to protect the success of the past. In Lumkin and Dess research stated that entrepreneurial orientation to affect the performance of the company.

\section{Literature}

In this era of globalization in need companies that have a competitive advantage for the company to survive. A competitive advantage according to Goyal \& Giri (2001) is the ability of a company to achieve economic gains in profits which can be achieved by competitors in the same market. Competitive advantage can be defined as the ability of the company to create value that is not owned and cannot be imitated by competitors (Pizam, 2010), (Li et al., 2006) and (Lenny at al., 2007). According to Reed et al. (2000) that the competitive advantage of the company as a competence that distinguishes it from competitors so companies dominate certain markets and to maintain its position. Competitive advantage will succeed if supported by manager performance.

While the performance manager according to Gupta and Govindarajan (1984); Nouri and Parker (1998) is the ability of managers in carrying out their responsibility for product quality, product quantity, the accuracy of product completion, achievement of the budget, cost reduction and revenue enhancement. Meanwhile, according to Purnama (2014) manager performance is the ability of managers that includes four aspects: knowledge, attitude, skills and Emotional maturity. Further Purnama stated that the manager performance will affect the performance of the business which in turn will affect the company's competitive advantage. According to Anwar (2000: 67) factors that affect the achievement of competitive advantage is: the psychological factor of capacity, the ability of employees consists of the ability of knowledge means that someone who has the ability knowledge better than others (above average).

From the above definition can be concluded that the performance manager is a manager's ability to use knowledge, attitudes, and talents in performing their duties in order to reach the target of the manager's job. In this study, the indicators used are the indicators developed by Purnama (2014) and Anwar (2000), which includes knowledge, attitude, skills and Emotional maturity which are then used as an indicator in this study.

Meanwhile, related to entrepreneurial orientation in the opinion of Porter (2008) that entrepreneurial orientation can be interpreted as a strategy to benefit the company to compete more effectively in the same marketplace. Meanwhile, another sense mentioned by Utami (2012: 4) who argued that entrepreneurial orientation is a process, practice and decision-making activities that led to the new entry. Entrepreneurial orientation appears from the perspective of a strategic choice which states that the chances for successful new entry are highly dependent on the performance of the objectives. According to Knight at al. (2002) Entrepreneurial orientation is a tendency of individuals to innovate, proactive and willing to take risks to start or manage a business. Entrepreneurial orientation is an organizational behavior concept related to innovativeness, proactive and risk-taking (Miller, 1983) coupled with the autonomy and competitive 
aggressiveness (Lumpkin and Dess, 1996) and (Zahra and Covin, 1995). While Drucker (1985) and Man at al. (2002) suggests there are six main areas to develop entrepreneurial orientation are the opportunity, relationship, conceptual, organizing strategic and commitment competencies.

Of the various terms above, it can be concluded that the entrepreneurial orientation is the company's strategy to enter into the specific market in which there are activities which depend on the purpose of the company itself. In this study, the indicators used are the indicators developed by (Miller, 1983), (Lumpkin and Dess, 1996) and (Zahra and Covin, 1995) innovativeness, proactive, risk-taking, autonomy and competitive aggressiveness, while associated with creativity is an activity or activities that bring the results that are new, useful and understandable. Creativity emphasizes three capabilities, which is associated with the ability to combine, problem-solving skills, creative ability operationally. Creativity is the ability to develop new ideas and to find new ways to solve problems to deal with business opportunities. Research Williams (1980) about a creative personality with dimensions: attitudes, motivations, interests, styles of thinking and habits of conduct. Meanwhile, according to Suryana (2006) states that creativity is to think something new.

Creativity can be concluded that a person's ability in generating new ideas and in accordance with the demands of the state, where the ideas and needs. That ability can be received and perceived by society as something natural surrounding and not something that makes no sense when new ideas are generated deemed able to meet the needs. Creative people will have the attitude, creative thinking, and behavior when their performance is fostered early because creativity is a process. In this study, the indicators used are the indicator developed by Williams (1980) includes dimensions: attitudes, motivations, interests, styles of thinking and habits of conduct.

\section{Methodology}

In general, this study aims to describe and analyze the factors affecting the performance of managers consisting of entrepreneurial orientation and creativity factors and their impact on competitive advantage. In accordance with its objectives, this study was designed as an explanatory study. The results obtained in this study are expected to provide an explanation of how entrepreneurial orientation and creativity affect the performance of managers and their impact on competitive advantage. Under the review of the nature of the relationship between variables, this study was designed as a research with the type of correlation. The relationship between these variables is presented in figure 1 . Samples of $10 \times 17$ number of 170 manager's small medium enterprises (SMEs) in the shoe industry Mojokerto East Java Province, according to the theory presented Ferdinand (2014) determination of the number of samples between 5 to with 10 multiply the number of indicators. The sampling technique uses random sampling techniques.

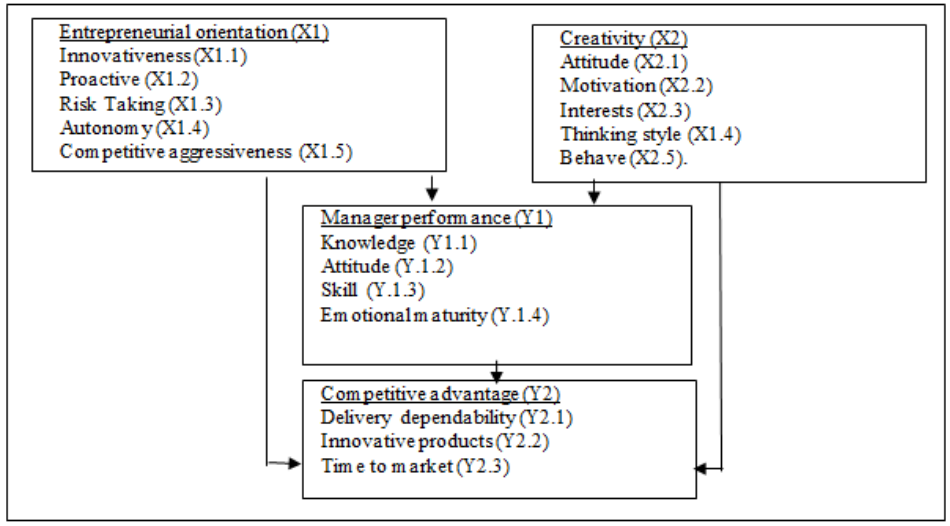

Figure 1: The relationship between the study variables

Source: Various theories 


\section{Results and Discussion}

\subsection{Confirmatory loading factor testing results analysis, critical path ratio and coefficient}

This study used factor analysis and regression model with structural equation modeling (SEM). Based on the results of testing the model, then obtained loading factor confirmatory and critical ratio as follows:

\subsubsection{Entrepreneurial orientation}

Results loading factor confirmatory and critical ratio of entrepreneurial orientation is as follows:

Table 1: Regression weight (loading factor confirmatory) standardized estimate (SE) and the critical ratio $(C R)$ indicator of entrepreneurial orientation factor

\begin{tabular}{|c|l|c|c|c|c|}
\hline No. & Indicators & $\begin{array}{c}\text { SE (loading factor) } \\
\text { good of fit }>0.4\end{array}$ & $\begin{array}{c}\text { CR good of } \\
\text { fit }>1.96\end{array}$ & $\begin{array}{c}\text { Probability (P) } \\
\text { good of fit }<0.05\end{array}$ & Specification \\
\hline 1 & Innovativeness & 0.569 & 2.960 & 0.003 & Good of fit \\
\hline 2 & Proactive & 0.844 & 3.300 & 0.001 & Good of fit \\
\hline 3 & Risk taking & 0.955 & 3.855 & 0.000 & Good of fit \\
\hline 4 & Autonomy & 1.214 & 4.154 & 0.000 & Good of fit \\
\hline 5 & Competitive aggressiveness & 1.000 & & 0.000 & Good of fit \\
\hline
\end{tabular}

Source: primary data are processed

Test results is presented in table 1 show that if seen from the loading factor confirmatory, that these four indicators above the value of 0.4 according to Ferdinand (2014) value loading factor that is allowed to come in the analysis model is greater than 0.4 , Ferdinand further said that while the CR required is greater than 1.96 at the level of $\alpha=0.05$ and the value of $C R$ showed that the four significant indicators by $C R>1.96$ and the value of the probability $(P)$ of $0.000,0.001$ and 0.003 less than 0.05 . From the above test results obtained five indicators that can be used as a measure of entrepreneurial orientation in explaining variables are: innovativeness, proactive, risk-taking, autonomy and competitive aggressiveness. These five indicators are jointly able to explain the variables and of five indicators are best able to explain the variable is autonomy, then competitive aggressiveness, followed by risk taking, further proactive and most recently innovativeness.

\subsubsection{Creativity}

Results and critical confirmatory factor loading ratio on job satisfaction in the following carefully:

Table 2: Regression weight (loading factor confirmatory) standardized estimate (SE) and critical ratio (CR) indicators of creativity factors

\begin{tabular}{|c|l|c|c|c|c|}
\hline No. & Indicators & $\begin{array}{c}\text { SE (loading factor) } \\
\text { good of fit }>0.4\end{array}$ & $\begin{array}{c}\text { CR good of } \\
\text { fit }>1.96\end{array}$ & $\begin{array}{c}\text { Probability (P) good } \\
\text { of fit }<0.05\end{array}$ & Specification \\
\hline 1 & Attitude & 0.974 & 3.627 & 0.000 & Good of fit \\
\hline 2 & Motivation & 0.862 & 3.238 & 0.001 & Good of fit \\
\hline 3 & Interests & 1.000 & & 0.000 & Good of fit \\
\hline 4 & Thinking Style & 0.800 & 2.637 & 0.008 & Good of fit \\
\hline 5 & Behave & 0.784 & 3.155 & 0.002 & Good of fit \\
\hline
\end{tabular}

Source: primary data are processed

Test results is presented in table 2 shows that when seen from the value of the loading factor, that the four indicators above 0.4 by Ferdinand (2014) which allowed the value of loading factors 
included in the analysis model is greater than 0.4 , Ferdinand further said to $(C R)$ required greater than 1.96 at the level of $\alpha=0.05$ and if seen from table 2 shows that the value of its CR fourth significant indicator with $C R>1.96$ and when seen at the level of $\alpha=5 \%$. It can be seen the value of the probability $(P) 0.000$ less than 0.05 . From the test results above obtained that the four indicators, all of which can be used as a gauge in explaining jointly variable creativity, namely: attitude, motivation, interests, thinking style and behave out of four indicators are best able to explain the variable creativity are interests, then attitude, followed by motivation, then thinking style of the most recent and behave.

\subsubsection{Manager Performance}

Results loading factor confirmatory and critical ratio of success in the meticulous effort are as follows:

Table 3: Regression weight (loading factor confirmatory) standardized estimate (SE) and critical ratio $(\mathrm{CR})$ indicators of manager performance factors

\begin{tabular}{|c|l|c|c|c|c|}
\hline No. & Indicator & $\begin{array}{c}\text { SE (loading factor } \\
\text { good of fit }>0.4\end{array}$ & $\begin{array}{c}\text { CR good of } \\
\text { fit }>1.96\end{array}$ & $\begin{array}{c}\text { Probability (P) } \\
\text { good of fit }<0.05\end{array}$ & Specification \\
\hline 1 & Knowledge & 1.262 & 4.314 & 0.000 & Good of fit \\
\hline 2 & Attitude & 3.925 & 2.300 & 0.000 & Good of fit \\
\hline 3 & Skill & 0.914 & 3.513 & 0.000 & Good of fit \\
\hline 4 & Emotional maturity & 1.000 & & 0.000 & Good of fit \\
\hline
\end{tabular}

Source: primary data are processed

Test results are presented in table 3 shows that when seen from the loading factor, that these four indicators value above 0.4 and if seen from table 3 value CR show that the four significant indicators with $C R>1.96$ and when seen at the level of $\alpha=5 \%$. It can be seen the value of the probability $(P) 0.000$ less than 0.05 . From the above test results showed that the four indicators, all of which can be used as a measure of the performance manager explaining variables are: knowledge, attitude, skills and emotional maturity. Four indicators are jointly able to explain the variable manager and the performance of these four indicators are best able to explain the variable is the attitude, then followed by emotional maturity and knowledge of the most recent is a skill.

\subsubsection{Competitive Advantage}

Results loading factor confirmatory and critical ratio of success in the meticulous effort are as follows:

Table 4: Regression weight (loading factor confirmatory) standardized estimate (SE) and critical ratio $(\mathrm{CR})$ indicators of competitive advantage factors

\begin{tabular}{|c|l|c|c|c|c|}
\hline No. & Indicator & $\begin{array}{c}\text { SE (loading factor) } \\
\text { good of fit }>0.4\end{array}$ & $\begin{array}{c}\text { CR good of } \\
\text { fit }>1.96\end{array}$ & $\begin{array}{c}\text { Probability (P) } \\
\text { good of fit }<0.05\end{array}$ & Specification \\
\hline 1 & Delivery Dependability & 1.000 & & 0.000 & Good of fit \\
\hline 2 & Innovative products & 0.088 & 2.158 & 0.031 & Not good of fit \\
\hline 3 & Time to market & 1.016 & 7.009 & 0.000 & Good of fit \\
\hline
\end{tabular}

Source: primary data are processed

Test results are presented in table 4 shows that when seen from the loading factor, that not all the indicators above the value of 0.4 and when viewed from the CR showed that of the third indicator with $C R>1.96$ and when seen at the level of $\alpha=5 \%$. It can be seen the value of the probability (P) 0.000 and 0.003 less than 0.05 . From the above test results showed that of the three indicators, 
only two of which can be used as a measure of competitive advantage in explaining variables are: delivery dependability and time to market. Both indicators are jointly able to explain the variable and the competitive advantage of both indicators are most able to explain the variable is the time to market and then delivery dependability.

The test results confirmatory factor and the path coefficient variables influence entrepreneurial orientation with indicators of attitude, motivation, interests, thinking style and behave, variable creativity namely: attitude, motivation, interests, thinking style and behave, manager performance are: knowledge, attitude, skills and emotional maturity and competitive advantage are: delivery dependability and time to market, the outline can be seen in figure 2 below:

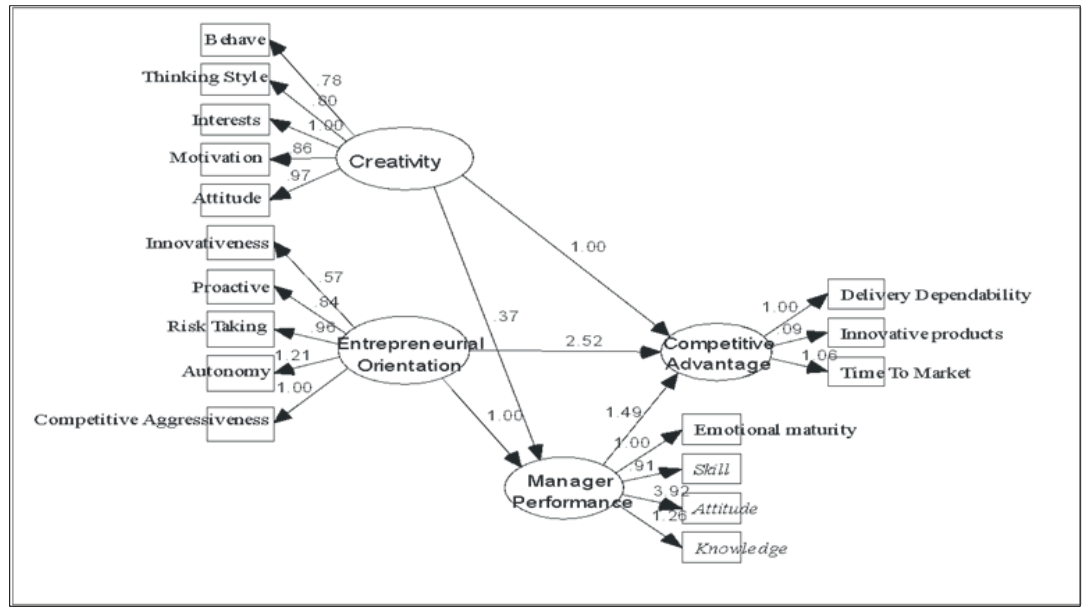

Figure 2: Confirmatory factor and the path coefficient variables influence entrepreneurial orientation, creativity and manager performance against competitive advantage

Source: primary data are processed

\subsection{Hypothetical testing results}

Results of calculations as presented in table 4

Table 4: Results of testing effects entrepreneurial orientation, creativity and performance manager of competitive advantage

\begin{tabular}{|c|c|c|c|c|c|}
\hline NO & Variable & Path coefficient & SE & $\mathrm{CR}$ & Probability $(\mathrm{P})$ \\
\hline 1 & Manager performance $\leftarrow$ Entrepreneurial orientation & 1.000 & & & 0.000 \\
\hline 2 & Manager performance $\leftarrow$ Creativity & 0.368 & 0.099 & 3.734 & 0.000 \\
\hline 3 & Competitive advantage $\leftarrow$ Entrepreneurial orientation & 2.514 & 0.564 & 4.464 & 0.000 \\
\hline 4 & Competitive advantage $\leftarrow$ Creativity & 1.000 & & & 0.000 \\
\hline 5 & Competitive advantage $\leftarrow$ Manager performance & 1.486 & 0.041 & 2.058 & 0.040 \\
\hline
\end{tabular}

Source: primary data are processed

Seen from table 4 above, with significant critical value ratio $>1.96$ and at $\alpha=0.05$ level (Ferdinand, 2014) it was found that 1). Entrepreneurial orientation significantly influences the performance manager with a probability value $(P)$ and the $C R$ value is perfect. 2). Creativity significant effect on creativity with a probability value $(P)=0.000$ from 3.734 CR 0.05 and smaller than 1.96 and 3 ). Entrepreneurial orientation significant effect on the competitive advantage with probability value $(P)$ $=0.000$ less than 0.05 and CR 4464 is greater than 1.96. 4). Creativity significant effect on the 
competitive advantage with a probability value $(P)=0.000$ less than 0.05 and the $C R$ value is perfect and 5). Manager performance significantly influence the competitive advantage with probability value $(P)=0.040$ is less than 0.05 and CR 2.058 is greater than 1.96.

Results of testing the effect of entrepreneurial orientation, creativity and manager performance against competitive advantage shows that entrepreneurial orientation influence the on manager performance with the value path coefficient of 1.000 , while the direct effect of entrepreneurial orientation to the competitive advantage of the value of the path coefficient of 2.541 , creativity effect on manager performance with value path coefficient of 0.268 , while the direct effect of the competitive advantage creativity path coefficient value of 1.00 and influence of manager performance against competitive advantages path coefficient value of 1.486 .

Result of this study to answer those very good multilevel models to describe models or accept the hypothesis. By analyzing the influence of entrepreneurial orientation, creativity and manager performance against the expected competitive advantage we are able to gain an understanding of the importance of entrepreneurial orientation factor, creativity and performance manager in improving the competitive advantage of small medium enterprises (SMEs) in the shoe industry Mojokerto East Java Province. In this study connects the four variables proposed in the model. The fourth of these variables include entrepreneurial orientation, creativity and manager performance and competitive advantage. Indicators of the four variables are as follows:

$\checkmark$ For the entrepreneurial orientation, variables are innovativeness, proactive, risk-taking, autonomy and competitive aggressiveness. Five indicators are jointly able to explain the variable and the entrepreneurial orientation of the five indicators are best able to explain the variable is autonomy, then competitive aggressiveness, followed by risk taking, further proactive and most recently innovativeness.

$\checkmark$ For creativity variables, namely: attitude, motivation, interests, thinking the style and behave. These five indicators are jointly able to explain the variables of the five indicators are best able to explain creativity is variable interests, then attitude, followed by motivation, then thinking the style of the most recent and behave.

$\checkmark$ For variable manager performance are knowledge, attitude, skills and emotional maturity. Fourth indicators are jointly able to explain the variable manager and the performance of these four indicators are best able to explain the variable is the attitude, then followed by emotional maturity and knowledge of the most recent is a skill.

$\checkmark$ For variable competitive advantage, namely: delivery dependability, innovative products and time to market. Of three indicators only two indicators that can explain the variable. Both indicators are jointly able to explain the variable and the competitive advantage of both indicators are most able to explain the variable is the time to market and then delivery dependability. In this study, in addition to finding a new model as mentioned above, also find the influence of variables influence entrepreneurial orientation, creativity to manage performance and competitive advantage as a hypothesis test results in table 4.

An explanation of the effect of entrepreneurial orientation, creativity to manage performance and competitive advantages are as follows:

\subsubsection{Effect of entrepreneurial orientation variables to manager performance and competitive advantage.}

Test results with SEM (structural equation modeling) through AMOS 4.0 shows that the entrepreneurial orientation positively affects Manager Performance. This finding indicates that the results were in line with what was mentioned by Wiklund and Shepherd (2003) stated that through the investigation of entrepreneurial orientation, we can explain the managerial process that allows the company to reach a position that is superior compared to its competitors, because the entrepreneurial orientation facilitates actions of the company to act on early signs from the company's internal and external environment (Lumpkin and Dess, 1996). Entrepreneurial orientation leads to a company's strategic orientation, covering also aspects of style, methods, and practices of specific entrepreneurial decision making. McGrath, (1996) stated that entrepreneurial orientation can be an important measurement of how a company is organized and is an important 
contribution of entrepreneurship to company performance. This study is also consistent with the results Solomon at al. (2013) which states that there is a significant contribution of some researchers concerned with the entrepreneurial orientation from time to time. It said further that the orientation of entrepreneurial orientation has a positive correlation with the performance of small businesses covering aspects: independence, innovation, courage to take risks, the aggressiveness of the competition and proactivity. Meanwhile, according to Gosselin (2005), that there is a significant relationship between entrepreneurial orientation defined by the company's performance. Entrepreneurial orientation refers to the processes, practices, and decision-making that led to the new input and has three aspects of entrepreneurship, that is willing to take risks, act proactively and always innovative (Lumpkin and Dess, 1996). Dare to take risks and dare to face challenges with exploitation or involved in business strategy where uncertainty is the likely result of entrepreneurial attitude orientation. Proactive reflects the willingness of entrepreneurs to dominate and competitors through a combination of aggressive and proactive action, such as introducing a new product or service over the competition and activities in anticipation of future demand to create change and shape the environment. Innovative refers to an entrepreneurial attitude orientation to engage creatively in the process of the experiment on new ideas that enable generate new production methods resulting in new products or services, either for the present or to the future market. Entrepreneurial orientation is associated closely with the increased profits that a person who has an entrepreneurial orientation have the opportunity to take profits, which in turn positively affects business performance (Wiklund and Shepherd, 2003). Therefore, companies are increasingly innovative, proactive, and dare to take risks tend to be able to perform better business.

\subsubsection{Creativity variable effect on manager performance and competitive advantage}

Test results with SEM (structural equation modeling) through AMOS 4.0 indicates that the variable creativity positive effect on manager performance. This finding indicates that the results were in line with what was mentioned by Yang and Choi (2009) explains that there is a significant positive relationship between creativity on performance. Creativity is important to the organization as a creative contribution not only can help organizations become more efficient and more responsive to the performance but also help the organization adapt to change, grow and compete in the global market (Lee and Tan, 2012). As delivered Shalley et al. (2004) that employees who generate creative new ideas and useful about the product organization, practices, or procedures. Moreover, these people may create a good effect for the organization. Shalley et al. (2004) stated that the new ideas that creative employees can be transmitted to other employees in the organization. Consequently, such creativity at the individual level, are likely to lead to the development of innovative products at the organizational level. Positive effect on employee creativity and organizational innovation will improve manager performance, the creativity of employees that work is expected to turn creative ideas into innovative product ideas and implementation by the employee should be considered in measuring creativity (Mumford et al., 2002).

\subsubsection{Performance manager variable influence on the competitive advantage}

From the test results with SEM (structural equation modeling) through AMOS 4.0 indicates that the variable manager performance positively affects competitive advantage. This finding indicates that the results were in line with what was mentioned by Purnama (2011) showed that the ability of businesses has a significant impact on business success. Innovative refers to an attitude of entrepreneurs to engage creatively in the process of the experiment on new ideas that enable generate new production methods resulting in new products or services, either for the present and into new markets. Innovation capabilities associated with perception and activity against business activities new and unique Qureshi et al. (2011) in this study mentioned variables influence the entrepreneurial orientation towards competitive advantage. 


\section{Conclusions}

Based on the test results and discussion of research can be concluded that the factors affecting manager performance and impact on the competitive advantage as follows:

First, the variable entrepreneurial orientation that includes indicators (innovativeness, proactive, risk-taking, autonomy and competitive aggressiveness) effect on manager performance indicators that includes indicators (knowledge, attitude, skills and emotional maturity).

Second, the variable entrepreneurial orientation which includes (innovativeness, proactive, risk-taking, autonomy and competitive aggressiveness) affects the competitive advantage with indicators that includes indicators (delivery dependability, innovative products and time to market).

Third, creativity variables which include (attitude, motivation, interests, thinking the style and behave) affect the performance manager with indicators covering (knowledge, attitude, skills and emotional maturity).

Fourth, creativity which includes indicators (attitude, motivation, interests, thinking the style and behave) affect the competitive advantage with indicators covering (delivery dependability, innovative products and time to market).

Fifth, manager variable performance indicators that include indicators (knowledge, attitude, skills and emotional maturity) affect the competitive advantage with indicators covering (delivery dependability, innovative products and time to market)

\section{Reference}

Coelho, F., Augusto, M., \& Lages, L. F. (2011). Contextual factors and the creativity of frontline employees: The mediating effects of role stress and intrinsic motivation. Journal of Retailing, 87(1), 31-45.

Gosselin, Maurice, (2005). An Empirical Study of Performance Measurement in Manufacturing Firm, International Journal of Productivity and Performance Management, 54(5/6), 419-437

Gupta, A. K., \& Govindarajan, V. (1984). Business unit strategy, managerial characteristics, and business unit effectiveness at strategy implementation. Academy of Management journal, 27(1), 25-41.

Goyal, S. K., \& Giri, B. C. (2001). Recent trends in modeling of deteriorating inventory. European Journal of operational research, 134(1), 1-16.

Kim, W. C., \& Mauborgne, R. (2004). Blue Ocean Strategy. Harvard Business Review, 82(10), 76-84.

Knight, Mc D. H., Choudhury, V., \& Kacmar, C. (2002). The impact of initial consumer trust on intentions to transact with a web site: a trust building model. The Journal of Strategic Information Systems, 11(3), 297323.

Kwasniewska, J., \& Necka, E. (2004). Perception of the climate for creativity in the workplace: the role of the level in the organization and gender. Creativity and Innovation Management, 13(3), 187-196.

Lee, L. Y. dan Tan, E. (2012). The Influences of Antecedents on Employee Creativity and Employee Performance: A MetaAnalytic Review. Interdisciplinary Journal of Contemporary Research In Business, 4(2): 984-996.

Lennox Henry (2013). Intellectual Capital In A Recession, Evidence from UK SMEs. Journal of Intellectual Capital, 4(1), 84-101.

Lenny Koh, S. C., Demirbag, M., Bayraktar, E., Tatoglu, E., \& Zaim, S. (2007). The impact of supply chain management practices on performance of SMEs. Industrial Management \& Data Systems, 107(1), 103124.

Li, S., Ragu-Nathan, B., Ragu-Nathan, T. S., \& Rao, S. S. (2006). The impact of supply chain management practices on competitive advantage and organizational performance. Omega, 34(2), 107-124.

Lumpkin, G. T., \& Dess, G. G. (1996). Clarifying the entrepreneurial orientation construct and linking it to performance. Academy of management Review, 21(1), 135-172.

Man, T.W.Y., Lau. T. and Chan, K.F. (2002). The Competitiveness of Small and Medium Enterprises: A Conceptualization with Focus on Entrepreneurial Competencies. Journal of Business Venturing, 17(2), 123-142.

McGrath, R. G. (1999). Falling forward: Real options reasoning and entrepreneurial failure. Academy of Management review, 24(1), 13-30.

Miller, D. (1983). The correlates of entrepreneurship in three types of firms. Management science, 29(7), 770791.

Mumford, M. D., Scott, G. M., Gaddis, B., \& Strange, J. M. (2002). Leading creative people: Orchestrating expertise and relationships. The leadership quarterly, 13(6), 705-750.

Nouri, H., \& Parker, R. J. (1998). The relationship between budget participation and job performance: the roles 
of budget adequacy and organizational commitment. Accounting, Organizations and Society, 23(5-6), 467-483.

Pizam, A. (2010). Creating memorable experiences. International Journal of Hospitality Management, 29(3), 343.

Porter, M. E. (2008). The five competitive forces that shape strategy. Harvard business review, 86(1), 25-40.

Purnama, C. (2014). Influence of analysis work ethic to improve the ability and small industrial business success (studies in small industrial companies in East Java). British Journal of Business and Management Research, 1(2), 1-11.

Purnama, C. (2011). Motivasi dan Kemampuan Usaha Dalam meningkatkan Keberhasilan Usaha Industri Kecil (Studi Pada Industri Kecil Sepatu di Jawa Timur). Jurnal Manajemen dan Kewirausahaan (Journal of Management and Entrepreneurship), 12(2), 177-184.

Qureshi, J. A., Hayat, K., Ali, M., \& Sarwat, N. (2011). Impact of job satisfaction and organizational commitment on employee performance, evidence from Pakistan. Interdisciplinary Journal of Contemporary Research in Business, 3(4), 642-657.

Reed, R., Lemak, D. J., \& Mero, N. P. (2000). Total quality management and sustainable competitive advantage. Journal of quality management, 5(1), 5-26.

Shalley CE, Zhou J, Oldham GR. (2004). The effects of personal and contextual characteristics on creativity: where should we go from here? Journal of Management, 30(6):933-58.

Solomon, G., Frese, M., Friedrich, C., \& Glaub, M. (2013). Can personal initiative training improve small business success? A longitudinal South African evaluation study. The International Journal of Entrepreneurship and Innovation, 14(4), 255-268.

Wiklund, J., \& Shepherd, D. (2003). Knowledge-based resources, entrepreneurial orientation, and the performance of small and medium-sized businesses. Strategic management journal, 24(13), 1307-1314.

Yang, S. B., \& Ok Choi, S. (2009). Employee empowerment and team performance: Autonomy, responsibility, information, and creativity. Team Performance Management: An International Journal, 15(5/6), $289-301$.

Zahra, S. A., \& Covin, J. G. (1995). Contextual influences on the corporate entrepreneurship-performance relationship: A longitudinal analysis. Journal of business venturing, 10(1), 43-58.

Reference to a book:

Anwar Prabu Mangkunegara, (2000). Manajemen Sumber Daya Manusia Perusahaan. Bandung : PT Remaja Rosdakarya.

Besant J., Whyte J., and Neely A. (2005). DTI think Piece Management of creativity and design within the firm, Advanced Institute for Management (AIM) and Imperial College.

Drucker PF. (1985). Innovation and entrepreneurship: practice and principles. New York: Harper and Row, Publishers.

Ferdinand, Augusy, (2014). Metode Penelitian Manajemen, Pedoman Penelitian Untuk Penulisan Skripsi, Tesis dan Disertasi IImu Manajemen, Edisi 5, BP UNDIP Guilford, J.P. (1954). Psychometric Methods. Second edition. Tokyo: Kogakusha Company Ltd.

Mulyadi dan Johny Setyawan, (2000), Sistem Prencanaan dan Pengendalian Manajemen, Edisi 1, Penerbit Aditya Media, Yogyakarta.

Suryana, (2006). Kewirausahaan. Pedoman Praktis, Kiat dan proses menuju sukses edisi revisi: Salemba empat, Jakarta.

Utami, Munandar, S.C.. (2012). Pengembangan Kreativitas Anak Berbakat. Rineka Cipta. Jakarta.

Williams, F. (1980). Creativity Assesment Packet: Manual East Aurara,NY, DOK Publisser. 